\title{
Belphégor
}

\section{Massification and its Critique in the Nineteenth Century History of Ideas: József Eötvös on Popular Meanings and Public Life}

\section{Hanna Orsolya Vincze}

\section{(2) OpenEdition}

Journals

Electronic version

URL: https://journals.openedition.org/belphegor/2312

DOI: $10.4000 /$ belphegor.2312

ISSN: 1499-7185

Publisher

LPCM

\section{Electronic reference}

Hanna Orsolya Vincze, "Massification and its Critique in the Nineteenth Century History of Ideas: József Eötvös on Popular Meanings and Public Life ", Belphégor [Online], 18-1 | 2020, Online since 04 March 2020, connection on 29 June 2021. URL: http://journals.openedition.org/belphegor/2312 ; DOI: https://doi.org/10.4000/belphegor.2312

This text was automatically generated on 29 June 2021.

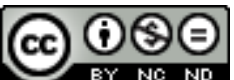

Belphégor est mis à disposition selon les termes de la Licence Creative Commons Attribution - Pas d'Utilisation Commerciale - Pas de Modification 4.0 International. 


\title{
Massification and its Critique in the Nineteenth Century History of Ideas: József Eötvös on Popular Meanings and Public Life
}

\author{
Hanna Orsolya Vincze
}

\section{Introduction}

1 Overviews of the concept of mass culture place the emergence of the term and the phenomena it denotes between the 1920's and the 1930's. This is the period, the argument goes, of the rise of mass culture produced and marketed by industrial techniques, for masses that are no longer held together by traditional values, that no longer form small communities ${ }^{1}$ (Strinati 2004: 5.) Ever since, one of the central questions guiding the study of mass culture has been its relationship to political power and public life:

Is popular culture there to indoctrinate the people, to get them to accept and adhere to ideas and values which ensure the continued dominance of those in more privileged positions who thus exercise power over them? Or is it about rebellion and opposition to the prevailing social order? Does it express, in however an imperceptible, subtle and rudimentary manner, resistance to those in power, and the subversion of dominant ways of thinking and acting? ${ }^{2}$

This paper investigates the way the relationship between popular culture and public life was addressed before the rise of mass culture in $20^{\text {th }}$ century by József Eötvös, one of the most prominent Central European political thinkers of the time - from a vantage point from which several later developments could already be foreseen. His most important work of political theory, The Dominant Ideas of the Nineteenth Century and Their Impact on the State, ${ }^{3}$ offered a criticism of the modern phenomena of massification and industrialisation of culture, and the accompanying phenomena of homogenisation, from the point of view of their consequences on the organisation of the state and on 
public life. Apart from offering his critique, Eötvös also argued for the importance of understanding the meanings and uses of popular ideas.

The case of Eötvös and of The Dominant Ideas points to several wider phenomena in the history of mass culture and of thinking about mass culture. It shows how the political language of aristocratic liberalism, that of Tocqueville, Mill, Burckhardt or Eötvös was one of the first attempts at articulating such a critique in a manner that surpassed the traditional "elite" criticism of the "vulgus" by pointing to the wider mechanisms at work in the new spatial realities of the modern city: the cultural realities of commodification and homogenization, and the political realities of the manufacturing of popular opinion in the popular press, through opinion polls and petitions. The importance of Eötvös' work further lies in his going beyond the aristocratic liberal critique and its educational project, and pointing to the need to understand the new meaning-making practices in order to be able to articulate the meanings and stakes attached to the newly popular ideas.

\section{Eötvös and The Dominant Ideas}

4 Today, Eötvös is known primarily as a novelist, author of novels addressing the pressing social and political issues of his times: revolutionary transformations, social relations, power and corruption, feudalism and modernity. As a politician, he held office in the revolutionary government of 1848 , serving as minister of Religion and Education, a position to which he returned in 1867, passing the Elementary Education Act. In The Dominant Ideas he looked for the causes of the failure of the reform movement by looking at the meanings attributed to the dominant ideas of the times: liberty, equality and nationality. Issues of nationality stood at the centre of his interests both as a politician and a political thinker, and The Dominant Ideas, as well as his writings on nationality rights, are today mostly read by students of national movements and minority issues. The most recent collective volume on his work, celebrating the two hundredth anniversary of his birth, focused on his intellectual biography, his fiction writing, his opinions on the national question, his career as a politician, his educational policies, and the "Eötvös tradition" in the education system. ${ }^{4}$

5 The Dominant Ideas was written after the failure of the 1848 Hungarian revolution, and grappled with the sources of this failure and the conditions required for the success of social and political reforms. The sweeping changes of 1848 throughout Europe, Eötvös wrote, were possible because many different people shared the dominant ideas of the time: liberty, equality and national independence. The movements that tried to implement these ideas, however, failed. Thus, either the ideas were wrong, or they were misunderstood by those meant to put them into practice.

6 Eötvös's reflections on the popular meanings and the commodification of culture and the media are formulated in the context of his wider argument on the nature of the dominant ideas and the attempts made to realize them. The key problem of the work, as the title suggested, was the relationship between the ideas of liberty, equality and national identity, and the state. Starting from the premise that "the only natural state for mankind is in society" and that "the dissolution of every State existing now is unthinkable without the destruction of our civilization," Eötvös then showed how these dominant ideas contradicted each other in the interpretation given to them by the elites, and that if realized in their current interpretation, they were to lead to the 
disintegration of the existing states. He then argued that the meaning people, in general, attached to the dominant ideas of the $19^{\text {th }}$ century was not the same as the one given to them by those who have tried to realize them. Moreover, the meaning generally attached to the dominant ideas by the common people, not only did not contradict the state, but in fact presupposed the formation of larger ones. The main misunderstanding revolved around the idea of liberty, which was redefined as equality, i.e. equal participation, direct or indirect, in political power for all people. As this kind of equality could only be realised by limiting individual liberty, in order to counteract the differences in individual means and abilities, liberty and equality became mutually exclusive. Equal political participation gave rise to the idea of popular sovereignty, which then gave states unlimited powers, again threatening individual liberty and even leading to despotism. National identity ended up also being used a pretext for a strife for power and domination, becoming therefore opposed to both liberty and equality.

7 Conclusions to the first volume quoted Tocqueville's Democracy in America to underpin the claim that the pursuit of order and equality in the state, with the state regulating every aspect of life, stalled progress and was a form of tyranny or despotism, even if based on popular sovereignty; this was the form of oppression threatening democracies. Current societies had developed based on the fundamental idea of liberty. The pursuit of the dominant ideas of equality and national self-determination in their current conception, as equal dominion or domination over other nationalities, with liberty defined as the rule of majorities over others, would either lead to the destruction of the extant states and societies, or to the creation of absolute state power. Either the state, or society will have to give. The question was: how is it possible to uphold the dominant ideas and still be able to maintain large states?

The second volume posited that, in fact, the meaning people attached to these ideas was quite different. Historically, as well as at the time, people defined liberty as freedom from domination. Even the continuous growth of state power, evident in history, was possible because, for long, people had only been pursuing individual autonomy. They only started seeking participation in power when the state started encroaching on such individual autonomies. The main goal of the age continued to be liberty, and the fight for equality was only important to people as a means to achieve this liberty. The reaction to 1848 was only possible because people lost their enthusiasm for the results of the revolution, because measures like universal suffrage, unlimited power of elected legislatures, juries, the free press or the unlimited right of assembly, did not correspond to what they sought in the name of liberty. People rather understood liberty as the state in which one could fully make use of one's abilities, equality as a means to achieve freedom, and national self-determination as the application of the idea of liberty to whole nations. Based on this understanding of the dominant ideas, volume two put forward a strong criticism of state centralisation, a criticism in fact of what Eötvös himself, later on, were to argue for as a minister: ${ }^{6}$ a constitutional monarchy with strong, autonomous local governments seen as guarantees of the fundamental value of liberty. 


\section{The political consequences of massification: the aristocratic liberal critique}

Eötvös's book is an unlikely source for ideas on popular culture. The author was a political thinker primarily speaking the language of European aristocratic liberalism, what Alan Kahan describes as a particular historical perspective and analysis of society and politics, centred around the values of liberty, individuality and diversity - values they saw threatened by the centralised, potentially despotic state, the predominance of commercial spirit and of material interests. ${ }^{7}$ Yet the interest of these thinkers in preserving individual freedom and diversity made them especially sensitive to the consequences of the processes of massification, commodification and marketization that are today seen as central to the concept of mass culture, as well as to the political consequences of these processes, to the traditionally uneasy relationship between mass meaning-making and public life.

Kahan's book discussed Alexis de Tocqueville, John Stuart Mill and Jakob Burckhardt as the main advocates of this distinctive discourse. Although coming from different national traditions, and with divergent views on many issues, such as the notion of historical progress, the meaning of equality or the role of the state in society, they all saw the Enlightenment and the French Revolution as the beginning of modernity, bringing about the birth of the commercial spirit, a taste for uniformity, middle class domination, clashes between the middle and lower classes, and "the steady encroachment of the state on the domains of all other social powers and on the freedom of the individual." ${ }^{8}$ The French Revolution played a pivotal role in the process because, after a first stage of fighting for liberty, it turned into a strife for equality, which became a threat to liberty, entailing the love of uniformity, unlimited popular sovereignty, and announcing the the despotism of the majority.

11 In terms of cultural consequences, they saw these developments as leading to mediocrity: mass taste and purchasing power was to be satisfied by speedy production and cheap, uniform products. This has led to the disappearance of the old, elite and exclusive reading public that made it possible for authors to allocate the necessary time and energy to produce out-of-the ordinary work. ${ }^{9}$

12 In terms of political consequences, centralisation and uniformisation brought about isolation, the breakdown of traditional ties and the destruction of local selfgovernment, itself a form of political participation and liberty. Centralisation and increased homogeneity also brought about the rise of the importance, but also of the homogeneity of public opinion:

Through the press and through peer pressure, public opinion controlled individual behaviour and exercised a sometimes decisive influence on the state. It also participated in the state directly, in the form of voting. Yet opinion was in turn subject to manipulation by the state, through both government influence on the press and control of suffrage. Thus, from the aristocratic liberals' prospective, the state appeared in relation to the majority at one moment as a tool, at the next as a master. $^{10}$

13 Their criticism of the modern phenomena of massification and commercialisation, and especially of their political consequences, however, did not make aristocratic liberals anti-modern. Modern developments threatened their central values, but it was not the old Regime or traditional aristocracy that they saw as guarantors of these values. 
Rather, they looked at the Revolution and the ensuing developments in order to find a way to uphold their values, but they were themselves "partisans of modernity." 11 They all supported, for example, the free press, but also pointed to the dangers of mass opinion-making. They supported universal suffrage, but also pointed to the dangers inherent in the lack of political education and the rise of demagoguery. Their main hopes for avoiding these dangers lay in education, "both in the broad sense of political participation and intellectual development and in the narrow sense of what could be done in the schools." ${ }^{12}$ Their major writings, like Burckardt's cultural histories or Tocqueville's Democracy in America were meant to be part of an educational effort. Their emphasis on education, Kahan argues, was a central characteristic of their modern humanist thinking. Modern humanism, though having many links and continuities with Renaissance civic humanism, differed from it in terms of the place it gave to virtue. Virtue was no longer to be found in the public realm, but was rather to be pursued in the private realm by private individuals. Thus, "the rhetorical world of modern humanism began to acquire a new concern with the individual apart from society, a concern utterly foreign to the classical and Renaissance perspectives." ${ }^{13}$

Situating Eötvös on the palette of contemporary European thought has always been a challenge to his students. Summaries like "individual contentment versus common good, market economy versus state-governed production, that is controlled economic system," ${ }^{14}$ which make Eötvös a proponent of classical liberalism understood in terms of individual vs. state, free market economy vs. state intervention, can easily be contrasted to passages like the following: "as long as thousands can be found everywhere who have no other freedom but the freedom to die of starvation without being compelled to work, it cannot be said that mankind must seek new paths because it has fulfilled the tasks set by Christianity." ${ }^{15}$ Passages like the latter ask for qualifying his-and generally $19^{\text {th }}$ century Hungarian-liberalism as being "in fact possessed of a unique and extremely effective social sensitivity." ${ }^{16}$ His "liberal Catholicism" ${ }^{17}$ or "liberal traditionalism," 18 and his acknowledgement of historic rights further complicate the picture. The monograph attempting the most comprehensive reconstruction of Eötvös's project argued that The Dominant Ideas cannot be discussed in a single intellectual context, as the various problems this work raised were discussed within the frameworks of various intellectual traditions, a characteristic of cultures relying on received ideas. ${ }^{19}$

Intellectual and personal connections between Mill, Tocqueville and Eötvös have been well-documented: he sent both copies of the book, and wrote to the latter that, upon reading his On Liberty, he was impressed by the similarity of their ideas, even though he was unaware of Mill's work in $1850 .{ }^{20}$ For our purposes, however, what is important is not the genealogy of his ideas, but the existence of shared elements, arguments and styles.

16 One of the main threads of Eötvös's argument was the discussion of the consequences of popular sovereignty. Eötvös shared with most liberal thinkers of his age what has been termed "the fear of democracy": they contemplated the consequences of political participation by the masses as a threat to extant culture and even property, ${ }^{21}$ and Eötvös wrote long passages on the threats of communism ensuing from themisunderstood, he aimed to show-principle of equality. of revolutions as "demagogue ideologists, adventurous mercenaries and bloodthirsty 
masses."22 In doing so he shared with Guizot, Tocqueville, Burckhardt or Mill a view of the masses as brutish, driven by the pursuit of private gains and material interests. ${ }^{23}$ Thus, the traditional topoi if the vulgus met with the criticism of the modern processes of massification.

However, this line of argument did not lead to a denial of the political capacity of the people. Although wary of popular revolutions, Eötvös, just like his aristocratic liberal contemporaries, was not a supporter of the old regime. He wanted the institutions to safeguard the individual, the people as well as the state against potential excesses, and looked for the institutions capable of doing so, the primary such safeguard being constitutionalism:

The fact that the masses are uncapable of ruling proves only that there cannot be completely democratic States without a constitution which will defend both the State and individuals against the ineptitude and the passions of the ruling power. It proves nothing else; those who see in the ineptitude of the masses a reason why they should not enjoy political rights are obliged, if they want to be consistent, to pronounce the same ban on other forms of government, monarchy for example; they will then arrive at Plato's utopia, in which the State is governed only by sages. 24

The people, whose conceptions the scholar of popular ideas was to understand, were difficult to define. But when looking at who the supporters of the ideals of equality and popular sovereignty were, Eötvös wrote, one was left only with the working classes living in the large cities:

If we ask, who then wants the principle of equality to be realized to the extent to which people are going into battle for it, the answer we shall get quite certainly be "The whole people wants it." If we go further and inquire who then is this "people," we shall be given answers which are bound to make us think of Beaumarchais's famous definition of press freedom. By this token the people includes all the inhabitants of France except the nobility, the clergy, parliamentary deputies, civil servants, capitalists, landowners, tenant farmers who employ several servants, workers who by virtue of their higher technical training are better paid, scholars, those who are too Catholic to want to subject the Church completely to the State etc. etc., in a word except all who have other views about equality and are consequently dubbed "aristos", so that we end by having to take the great expression "the people" to mean only proletarians, and of them only those who live in large cities and would lose nothing by an equal distribution of produce, because they belong to the lowest class of workers. ${ }^{25}$

Throughout the book, visions of suburban masses threatening public order returned as arguments against popular sovereignty understood as the rule of the majority. ${ }^{26}$ This held especially true for the people of the capitals, spatially closer to the seats of power, and thus capable of influencing decisions to a greater degree. Thus, with the popularisation of politics, space became one of the important factors defining political influence, by influencing the way the right of assembly or the right of resistance could be exercised. ${ }^{27}$ The assembly of large numbers of people in cities also made them more prone to the effects of demagogy,,$^{28}$ and led to the breakdown of traditional constraints on behaviour, like the requirements of mercy and those of morality. It was only individuals who could act mercifully, never the people, hence the cruelty of clashes between people and the dangers of nationalism:

The individual has a heart, the mass, never. A people is too large to be moved to pity. Why a clash between one people and another is always the most cruel, is something on which they might reflect who try so hard to stir up the dormant 
hatred between nations; they might reflect before sowing the seed from which their people will reap not greatness but general misery and degeneration. ${ }^{29}$ amass large numbers in order for a demand, for example a petition, to be considered, a result, Eötvös argued, of the principle of unlimited popular sovereignty. Under such conditions, people joined causes they did not identify with, hoping for some indirect 
benefit from joining a large, common cause, rather than upholding the unlimited diversity of interests and demands which had no chance of being addressed by any government. ${ }^{40}$

Modern governments took on to directing public opinion rather than attempting to decipher it: "In our day, when the business of creating public opinion is run as a craft, its peculiar techniques are far too well known for any further proof of what we have said to be needed." ${ }^{41}$ Although countries with a free press were much happier than those without one, the press was used by those with access to it, including the government, to direct public opinion. The process of industrialisation had reached public opinion as well, the manufacturing of which having become a craft with specific techniques..$^{42}$ As the people became the locus of sovereignty, they also became the focus of similar techniques of flattery as the crowned heads had before. Thus, the popular public became similar to its feudal predecessor, both being the objects of cajolery:

People are always found in despotisms, where the feelings of the ruler decide State policy, who will regularly appeal to those feelings; so in absolute democracies there is no shortage of individuals who practice their own special craft by proclaiming the feelings and views of the people. The messages trumpeted by these seneschals and chamberlains of the people are just as shoddy as those which take wing in the courts of princes. If anybody should want to question the complete similarity between the toadies of courts and those of marketplaces, we recommend that they watch attentively those who appeal to the feelings and views of the people. ${ }^{43}$

In Eötvös's critique of the consequences of massification there recurs the centuries-old ambivalence of men of letters towards the opinion of the masses, which was both regarded as volatile and unreasoned, and as the basis of authority and a check on power. The response of the Enlightenment to the problem that governments' authority rested on opinion, but at the same time the opinion of the masses was capricious and prone to being manipulated, was of course to "enlighten" the public. It is in this enlightenment project that the ambition of aristocratic liberals to educate the people was also grounded. The idea of a managed public opinion recurs of course in Enlightenment political thought, including Rousseau or Voltaire, as a means for "supplying the public with opinion," a form of education of the masses..$^{44}$ In the work of the aristocratic liberals, however, educational aspirations were coupled with concerns over the capacity of governments and majorities to manipulate public opinion, a possibility enlarged by the newly professionalized techniques of public opinion research:

To sound public opinion has in our time become exclusively the task of the government and those who aspire to power; the same people are the worst placed to assess it correctly-first because they usually pay attention to it only in so far as it is related to the government of the State, that is to a matter on which most people have no opinion. ${ }^{45}$

When addressing the dangers inherent in uniform public opinion constructed by consciously employing manipulative techniques, Eötvös also spoke a language employed by Tocqueville, who famously discussed public opinion as a means of exercising the tyranny of the majority, a view also echoed by Mill. ${ }^{46}$

All these elements not only make Eötvös a Central European exponent of aristocratic liberalism. They also point to the fact that aristocratic liberalism was one of the languages in which the first critical analyses of the political consequences of mass cultural phenomena was cast. As we shall argue below, the contribution of József Eötvös 
to this early critique was his insistence on the need to understand the meanings people attached to popular ideas - an early argument for the need to study mass culture.

\section{Deciphering popular meanings: Eötvös's proposal}

Eötvös's work, apart from criticism and stressing the importance of civilizational improvement and education, also introduced a new perspective. In the opening chapters of the second volume of The Dominant Ideas, he formulated a proposal to identify popular meaning-making practices, and ultimately to decipher the meaning people attached to the ideas they rallied around. Liberty, equality and national identity, as commonly understood by those who had tried to achieve them, proved incompatible. Therefore, the argument went, either the ideas themselves were in some way wrong, or they were put into practice in a manner foreign to their common understanding. The task, then, Eötvös argued, was to try and decipher the meaning people attached to these ideas rather than theorise on their meanings, in order for these to be achievable in the state.

How were these popular meanings meant to be deciphered, especially as the masses tended to be inarticulate? In his history of the concept of public opinion, J.A.W. Gunn argued that the main reason the issue was not theorized in Britain was that the existence of an articulate public was taken for granted. ${ }^{47}$ Eötvös could make no such assumption. On the contrary, he wrote,

Masses need a rallying point. The shorter a word and the greater the variety of meanings that can be attached to it, the more suitable it is for this purpose. Such words are for millions usually only a substitute for ideas or for their accurate expression. Where nobody can express himself clearly, all agree on a word which enables them to think what they want. Even the apparently general enthusiasm for words like liberty, equality and fraternity does not entitle us to draw any conclusions about the ideas, wishes and aspirations of the people. ${ }^{48}$

Although there were professionals employed by the government or those seeking power, they only paid attention to public opinion inasmuch as it concerned matters of government, matters which, Eötvös pointed out, most people did not have an opinion about. ${ }^{49}$ Thus, professional public opinion research was compromised by the government and party interests behind them, and moreover was often concerned with directing rather than deciphering public opinion. A possible medium for articulating public opinion was the right to petition, but, as we have seen above when discussing the consequences of massification and homogenisation, petitions joined by masses could not be taken as expressions of shared meanings. The most important outlet, the free press, was also compromised by these processes. Even though the importance of the freedom of the press was beyond dispute, he argued, the press could hardly be regarded to be a mirror of public opinion. This would presuppose that journalists understood and expressed the opinions of the people and acted as carriers of the public interest, which, sadly, he commented, was rarely the case..$^{50}$

The only solution was then to look at the actions people undertook in the name of the dominant ideas, at the goals they pursued when rallying around certain ideas. People rallying around ideas acted emotionally, driven by feelings rather than by rational thinking. The importance of emotions, Eötvös argued, was in fact a characteristic of the times, and needed to be addressed if one was to understand what people meant. Emotions were also important in terms of organising the state, as mechanistic power 
that did not take into account emotions was only obeyed because perceived as unavoidable.$^{51}$ For example, understanding popular antipathy towards the police could lead to a better understanding of the meaning of liberty and equality for the people. Equality, understood as homogenisation and standardisation, manifested itself most strongly in the modern state in the work of the police. Yet in all states, antipathy towards the police ran high. This emotion, Eötvös argued, allows us to understand that it was in fact the principle of liberty, and not that of equality, that people held most important..$^{52}$

Apart from some scattered remarks like the interpretation of public antipathy towards the police, however, the book does not offer a systematic demonstration of how to reconstruct popular meanings. Thus, its importance remains at a theoretical level, as an argument for understanding popular meaning-making practices in order to formulate normative proposals for public life.

Historians of philosophy have interpreted Eötvös's proposal as an anti-philosophical stance that could be explained by socio-historical causes. J.C. Nyíri wrote in a study entitled "From Eötvös to Musil. Philosophy and its negation in Austria and Hungary"53 that $19^{\text {th }}$ century Hungarian intellectuals had in general such an anti-philosophical stance. This interpretation set up an opposition between "philosophy and its negation," or "pre-conceived ideas" and "action," situating Eötvös, and more generally the politically-minded $19^{\text {th }}$ century Hungarian thinkers, in the latter group, defined by "the conservative view according to which pre-conceived ideas cannot serve as a basis for sound political action. ${ }^{54}$

37 A different approach in interpreting Eötvös was suggested, though not elaborated upon, by Gábor Gángó, who saw the importance of Eötvös in attempting not only to search for solutions to the problems of national conflicts, but also in a methodological novelty. This novelty consisted, according to Gángó, in undertaking a conceptual analysis starting not from definitions, but from the statements made about the causes and reasons of such movements, resembling the methodology of the modern history of ideas. ${ }^{55}$ This interpretation focused on the role of ideas and their understanding in Eötvös's work, identified as having central importance in our own overview of The Dominant Ideas. Another key term in Eötvös's methodological proposal was experience. He introduced the importance of experience when pleading for the application of Bacon's inductive method, instead of the application of preconceived ideas. Gathering experience also meant incursions into the history of ideas, into the way they have been understood and the consequences with which they have been applied in history.

Among the various intellectual companions Eötvös can be and has been associated with, his congeniality with Tocqueville takes on a new dimension if we focus on the role they both ascribed to ideas in society. Apart from the similarities between the two authors in the analysis of modern public opinion formation, scepticism towards speculative philosophy or practical solutions like the importance of participation in local governments, ${ }^{56}$ Eötvös also shared with Tocqueville his understanding of the role of ideas in society. Tocqueville opposed political sociology to speculative philosophy, favouring the former, because of his conception of politically effective truth. ${ }^{57}$ The effective truth was what people were willing to believe: "Tocqueville's political science could, indeed, be described primarily as the study of the origins and effects of such popular opinions or even less articulate attitudes and sentiments." ${ }^{58}$ Similarities in their understanding of the working of public opinion, for example, thus stem from 
their shifting the focus of analysis, from seeking universally-valid general ideas to what people actually think, and to the political consequences of the meanings they attached to their ideas.

\section{Conclusion} phenomena of the popularisation of politics and the rise of mass movements, tastes or opinions from the point of view of their impact on their cherished values, primarily liberty. They regarded these phenomena with disquiet, as threatening. Eötvös's views on the increased role of urban masses, his views on public opinion and the press, his criticism of mediocrity in various domains of life, all connect him to the great aristocratic liberals of his times. In their work, the analysis of the consequences of massification and commodification of culture, of the standardization of popular ideas and even emotions, of the threats of the tyranny of majority opinion and the possibilities of manipulation inherent in the newly professionalized mass media and public opinion research, were coupled with an educational project, as part of which their major works were written. The main thrust of their criticism was aimed at the processes of standardisation and uniformity, threatening individual liberty.

This aristocratic liberal critique of the rise of mass politics and mass culture can thus be regarded as one the first attempts at articulating the relationship between popular culture and power, which later became central to the preoccupations of cultural studies. Eötvös's interest was not an interest in "popular culture" in any of the current connotations of the expression. Yet his critique, along with that of his intellectual companions, was one of the routes by which popular meaning-making practices came to the forefront of intellectual attention, and aristocratic liberalism as a political language can be regarded as one of the first languages in which the critique of the emergent, urban mass culture was cast.

Eötvös's main contribution to this literature is his argument for the need to understand what the masses meant when rallying around the dominant ideas of their times. In spite of his concern for their political consequences, Eötvös also saw the rising importance of popular meaning-making practices as unavoidable, and formulated a theoretical argument for trying to decipher them. Even though the actual examples of such interpretations, like his analysis of popular attitudes towards the police, are few, his proposal is an important addition to aristocratic liberal critique. In formulating his argument, Eötvös pointed to several components of mass meaning-making practices that needed to be understood if one was to design public institutions that held popular support: the importance of popular emotions, of the professionalised and marketized techniques of popularising both arts and political ideas. Thus, his criticism of popular ideas voiced his strong concern about the political consequences of populism and the process of massification, but at the same time argued for a better understanding of these ideas. His proposal for deciphering popular meanings focused on the actions undertaken in the name of ideas, and the emotions attached to them, and primarily meant to address the political consequences of popular ideas. Understanding these was meant not only as a contribution to cultural history, but also to a better understanding and even ordering of public life. 


\section{BIBLIOGRAPHY}

Bényei Miklós, Eötvös József könyvei és eszméi, Debrecen: Csokonai, 1996.

Czigány Lóránt, Az “Uralkodó eszmék” kritikai kiadása - angolul, Holmi 2000/11.1393-1398.

Eötvös József, A XIX. Század uralkodó eszméinek befolyása a államra. Ed. by Ambrus Oltványi. Budapest: Magyar Helikon, 1981.

Eötvös József, The Dominant Ideas of the Nineteenth Century and their Impact on the State. Volume 1. Diagnosis. Translated by D. Mervyn Jones. East European Monographs CDLXIII. New York: Columbia University Press, 1996.

Volume 2. Remedy. Translated by D. Mervyn Jones. East European Monographs CDLXIV. New York: Columbia University Press, 1998.

Fenyő István, Eötvös és Tocqueville. Aetas, vol. 22, 2007/1. 127-134.

Gángó Gábor, Anti-metaphysical reasoning and sociological approach: roads from nationalism to regionalism in the 19th-20th century Hungarian intellectual tradition. Studies in East European Thought, 60, 2008 (1-2). 17-30.

Gángó Gábor, Az államtudós Eötvös: ideiglenes fejlődéstörténeti vázlat .Holmi 2000/11.1388-1392. Gángó Gábor, ed., A kincset csak fáradsággal hozhatjuk napvilágra. Tanulmánykötet báró Eötvös József születésének 200. évfordulójára. Budapest: Eötvös József Collegium, 2013.

Gángó Gábor, Eötvös József uralkodó eszméi. Kontextus és kritika. Budapest: Argumentum Kiadó - Bibó István Szellemi Műhely, 2006.

Gángó Gábor, Evangéliumi erkölcs és egyéni szabadság. In Mihály Szegedy-Maszák -András Veres, eds. A Magyar irodalom történetei 1800-tól 1919-ig. Vol. 2.of A Magyar irodalom történetei. Budapest: Gondolat, 2007. 355-367.

Gerő András, Modern Hungarian Society in the Making: the Unfinished Experience. Transl. by James Patterson and Enikő Koncz. Budapest: CEU Press, 1995.

Gunn, J.A.W., Public Opinon. In Terence Ball, Farr, J., \& Hanson, R. L., eds., Political Innovation and Conceptual Change. Cambridge: Cambridge University Press, 1989. 247-265.

Kahan, Alan S., Aristocratic Liberalism. The Social and Political Thought of Jacob Burckhardt, John Stuart Mill and Alexis de Tocqueville. New York-Oxford: Oxford University Press, 1992.

Kelley, Donald R. , Cultural history. In Maryanne Cline Horowitz, ed., New Dictionary of the History of Ideas. Vol.2..New York: Charles Scribner's Sons. 513-516.

Nyíri J.C., From Eötvös to Musil. Philosophy and its negation in Austria and Hungary. In idem, ed., Austrian Philosophy: Studies and Texts, München: PhilosophiaVerlag, 1981.9-30.

Paul Bödy, Joseph Eötvös and the Modernization of Hungary, 1840-1870 : a Study of Ideas of Individuality and Social Pluralism in Modern Politics. New York : Columbia University Press, 1985.

Strinati, Dominic, An Introduction to Theories of Popular Culture. $2^{\text {nd }}$ ed. London and New York: Routledge, 2004.

Szilágyi Márton, Önösség és áldozat (Eötvös József: A karthauzi). In Gángó, ed., A kincset csak fáradsággal hozhatjuk napvilágra. 73-82.

Takács József, Modern magyar politikai eszmetörténet. Budapest: Osiris, 2007. 
Tamás G.M., Eötvös: a nyugat-keleti liberális. In idem, Törzsi fogalmak.Vol.2. Budapest: Atlantisz, 1999. 9-143.

Zuckert, Cathrine H. Political Sociology Versus Speculative Philosophy. In Ken Masugi, ed., Interpreting Toqueville's Democracy in America. Savage, Maryland: Rowman and Littlefield, 1991. 121-152.

\section{NOTES}

1. Dominic Strinati, An Introduction to Theories of Popular Culture, $2^{\text {nd }}$ ed., London and New York: Routledge, 2004, 5.

2. Ibid.,3.

3. The two-volume book was first published in German in 1851 and 1854, then in Hungarian in the same years. Modern editions: József Eötvös, A XIX .század uralkodó eszméinek befolyása az államra, ed. by Ambrus Oltványi, Budapest: Magyar Helikon, 1981.; The Dominant Ideas of the Nineteenth Century and Their Impact on the State, transl. by Mervyn Jones, vol.1, Diagnosis, New York: Columbia University Press, 1996, vol. 2, Remedy, New York: Columbia University Press, 1998. The text is quoted in English from Mervyn Jones's translation.

4. Gángó Gábor, ed., A kincset csak fáradsággal hozhatjuk napvilágra. Tanulmánykötet báró Eötvös József születésének 200. évfordulójára, Budapest: Eötvös József Collegium, 2013.

5. Eötvös, The Dominant Ideas,vol.1,89.

6. G.M. Tamás, "Eötvös: a nyugat-keleti liberális", in idem, Törzsi fogalmak, vol.2, Budapest: Atlantisz, 1999, 91.

7. Alan S. Kahan, Aristocratic Liberalism. The Social and Political Thought of Jacob Burckhardt, John Stuart Mill and Alexis de Tocqueville, New York-Oxford: Oxford University Press, 1992.

8. Ibid., 16.

9. Ibid., 50.

10. Ibid., 65 .

11. Ibid.,32.

12. Ibid.,126.

13. Ibid., 89.

14. Lóránt Czigány, “Az “Uralkodó eszmék” kritikai kiadása - angolul”, Holmi 2000/11., 1394.

15. Eötvös, The Dominant Ideas, vol. 2.,4.

16. András Gerő, Modern Hungarian Society in the Making: the Unfinished Experience, translated by James Patterson and Enikő Koncz, Budapest: CEU Press, 1995, 71.

17. Gábor Gángó, Eötvös József uralkodó eszméi. Kontextus és kritika, Budapest: Argumentum Kiadó Bibó István Szellemi Műhely, 2006, 133.

18. Paul Bödy, Joseph Eötvös and the Modernization of Hungary, 1840-1870 : a Study of Ideas of Individuality and Social Pluralism in Modern Politics, New York : Columbia University Press, 1985, 70.

19. Gángó, Eötvös József uralkodó eszméi, 17.

20. Miklós Bényei, Eötvös József könyvei és eszméi, Debrecen: Csokonai, 1996, 39-70.; István Fenyő, Eötvös és Tocqueville, Aetas, vol.22, 2007/1, 127-134.

21. József Takács, Modern magyar politikai eszmetörténet, Budapest: Osiris, 2007, 41.

22. Tamás, Eötvös: a nyugat-keleti liberális, 101. cf. "The masses instinctively feel that their power lies in physical strength, and they are very fond of reminding their opponents of this indisputable basis of that power." (Eötvös, The Dominant Ideas, vol.1, 242.)

23. cf. Kahan, Aristocratic Liberalism, 37.

24. Eötvös, The Dominant Ideas, vol.1, 235-236.

25. Eötvös, The Dominant Ideas, vol.2, 31. 
26. "I consider our civilisation too viable to be brought down by wild groups pressing from the suburbs towards the parliamentary building and threatening society with death beneath bloodstained banners." (Eötvös, The Dominant Ideas, vol.1, 104.)

27. Ibid., 127.

28. Ibid.,257.

29. Ibid.,400.

30. Márton Szilágyi, Önösség és áldozat (Eötvös József: A karthauzi), in Gángó, ed., A kincset csak fáradsággal hozhatjuk napvilágra, 76-78.

31. For an overwiew of the concept of culture in cultural history cf. Donald R. Kelley, Culturalhistory, in Maryanne Cline Horowitz, ed., New Dictionary of the History of Ideas,vol.2., New York: Charles Scribner's Sons, 513-516.

32. Gábor Gángó, Anti-metaphysical reasoning and sociological approach: roads from nationalism to regionalism in the 19th-20th century Hungarian intellectual tradition. Studies in East European Thought, 60, 2008 (1-2), 19-20.

33. Gábor Gángó, Evangéliumi erkölcs és egyéni szabadság, in Mihály Szegedy-Maszák -András Veres, eds., A magyar irodalom történetei 1800-tól 1919-ig (Vol. 2. of A magyar irodalom történetei), Budapest: Gondolat, 2007, 355.

34. Kahan, Aristocratic Liberalism, 130-131.

35. Eötvös, The Dominant Ideas, vol.2, 43.

36. "What is this? How is it possible that feudalism, which people fought with such hatred, which has been overcome by gigantic effort, has now become an object of the greatest interest, that the imagination relishes precisely the pictures of a period which was earlier despised as an age brute force and utter darkness?

If we investigate the reason for this calmly, we shall find that what attracts us so powerfully about the Middle Ages is precisely the manifestation of a higher degree of individual liberty." (Eötvös, The Dominant Ideas, vol.2, 43.)

37. "If we examine calmly what has happened since the eighteenth century, the zeal with which war has been declared on every national characteristic in the interest of uniformity, the determination with which the liberty of the individual has been subjected to the power of the State in all respects (first in the interest of absolute monarchy, then for the supremacy of the people), we shall find it impossible to be surprised either that the pressure has awakened the consciousness of national characteristics or that the striving of individual liberty has manifested itself most keenly in precisely this direction." (Ibid., 45.)

38. Ibid., 41.

39. "The omnipotence of the people's power is not a mere phrase. Since the people is present everywhere, it can extend its power equally to the least and the greatest; in a democracy, since State power is exercised precisely by those who at the same time represent public opinion, it is free even from moral constraints." (Eötvös, The Dominant Ideas, vol.1, 295.)

40. "The right to petition, exercised individually by every inhabitant of the State, would result in such a mass of demands partly trivial, partly mutually contradictory, that no government or legislature could even consider them; so if the individual citizen is to use his right to petition succesfully, he must not ask for what he wants, but subscribe to the wishes of others; if these were granted, he could expect to achieve his own aims indirectly."(Eötvös, The Dominant Ideas, vol.2, 27.)

41. Ibid., 26.

42. Ibid., 29.

43. Eötvös, The Dominant Ideas, vol.1,196-197.

44. Gunn, Public Opinon, 253.

45. Eövös, The Dominant Ideas, vol.2., 25-26. 
46. J.A.W. Gunn, Public Opinon, in Terence Ball, Farr, J., \& Hanson, R. L., eds., Political Innovation and Conceptual Change, Cambridge: Cambridge University Press, 1989, 259.

47. ibid, 250.

48. Eötvös, The Dominant Ideas, vol.2, 25.

49. Ibid.

50. Ibid.

51. Eötvös, The Dominant Ideas, vol.1., 280.

52. "If people in our day erected statues and temples to ideas and worshipped the principle of equality as a goddess, the college of priests most worthy of this deity would indisputably be the police. It is the police that is continuously responsible for the observance of the principle of equality, that watches the movements of all individuals, all their most trivial actions, from the cradle to the grave, indeed even their thoughts; it always sees that their power shall not go beyond the prescribed limits, that their minds shall not burst the banks of the channel dug for them by a high Studies Commission. The cornerstone of a constitution which people admire as the ideal of equality among the citizens is the police. (...) How can we explain the hostility to a system so salutary, indeed obviously necessary, in the interest of equality, except by supposing that in general liberty and not equality is regarded by the majority of mankind as a supreme good? Even the direction which poetry and art have taken most recently serves as proof of this." (Eötvös, The Dominant Ideas, vol.2., 42-43.)

53. In J.C. Nyíri, ed., Austrian Philosophy: Studies and Texts, München: Philosophia Verlag, 1981, 930.

54. Ibid. 17.

55. Gábor Gángó, Az államtudós Eötvös: ideiglenes fejlõdéstörténeti vázlat, Holmi 2000/11., 1390.

56. These similarities between the two have been discussed for example in Bödy op.cit. 73-75.

57. Cathrine H. Zuckert, Political Sociology Versus Speculative Philosophy, in Ken Masugi, ed., Interpreting Toqueville's Democracy in America, Savage, Maryland: Rowman and Littlefield, 1991., 121-152.

58. ibid, 134.

\section{ABSTRACTS}

Writing after the failure of the 1848 Hungarian revolution, József Eötvös, himself a prominent politician and novelist, grappled with the sources of the failure and conditions of success of social and political reforms. In his monumental work, The Dominant Ideas of the Nineteenth Century and their Impact on the State, he proposed that in order to understand the behaviour of the masses and design social and political reforms that will have popular support, one needed to understand the meanings people assigned to popular ideas-as opposed to meanings assigned to them by theorists. Popularity, in this approach, had three components: ideas around which people rallied, emotions that connected them to these ideas, and actions people undertook in their name. The way towards understanding these components was to understand the culture of the people in its various manifestations, from popular religiosity to literary and material culture. By re-reading Eötvös's work focusing on his conception of popular ideas, this paper investigates how the longstanding tension between popularity and the distrust in populism was articulated in a classic of nineteenth century central European political thought. 
INDEX

Mots-clés: mass culture, popularity, populism, public life, aristocratic liberalism

\section{AUTHOR}

\section{HANNA ORSOLYA VINCZE}

Babeș-Bolyai University, Cluj-Napoca

vincze.orsolya@fspac.ro

Hanna Orsolya Vincze is associate professor of communications at Babeș-Bolyai University, ClujNapoca. Her research interests focus on forms of public knowledge, historical and contemporary, with a special focus on the transfer of ideas between various cultural and political contexts. In pursuing these interests, she has published on the history of political thought as well as on the framing of public issues in contemporary news media. 